\title{
THE ASSESSMENT ON RNA QUALITY AND BANANA RIPENING GENES (MaGAPDH, MaACS1, AND MaACO1) FROM FLESH TISSUES WITH DIFFERENT PRESERVATION METHODS
}

\author{
ANNISA AMALIA $^{1}$ and HUSNA NUGRAHAPRAJA ${ }^{1,2^{*}}$ \\ ${ }^{1}$ School of Life Sciences and Technology, Institut Teknologi Bandung (ITB), \\ Jalan Ganesa 10, Bandung 40132, Indonesia \\ ${ }^{2}$ Bioscience and Biotechnology Research Center, Institut Teknologi Bandung (ITB), \\ Jalan Ganesa 10, Bandung 40132, Indonesia \\ *E-mail:nugrahapraja@sith.itb.ac.id
}

Accepted 24 April 2020, Published online 6 July 2020

\begin{abstract}
The preservation of banana fruit is vital to ensure ripening quality during the transportation process. The quality of banana can be defined using the gene expression marker, which needs high-quality RNA. However, when access to the laboratory is difficult, during long-distance transportation, lack of liquid nitrogen or refrigerator, we need an alternative for preservation methods, so the sample and the extracted RNA are still in excellent conditions. Aim of our research is to find the best preservation methods and test the genes expression marker of Cavendish banana flesh tissues without using the liquid nitrogen. In this study, we performed preservation methods for RNA extraction by directly storing the flesh tissues at $-80^{\circ} \mathrm{C}$ refrigerator and combined with the use of various flesh cutting time $(0,19$, and 30 minutes). We measured the total RNA yield, absorbance ratio of 260/280, and checked the expression of MaGAPDH, MaACS1, and MaACO1 genes using Reverse TranscriptasePCR (RT-PCR). As a result, we found that the preservation methods did not affect the quality of RNA and the genes expression as well. Although the gene expression analysis need to be confirmed in future using quantitative PCR (qPCR) analysis. However, our preservation methods can be used as an alternative preservation method.
\end{abstract}

Key words: Flesh tissues, RNA quality, preservation methods, banana ripening genes, RT-PCR

\section{INTRODUCTION}

In Indonesia, banana is produced highest compared to other fruits. The total production of banana in Indonesia can reach 4.5 million tonnes of 74751 ha harvested area (Molina et al., 2005). However, the productivity of banana needs to be improved, especially considering the short shelf life of banana. In order to assess the ripening quality of banana, we can use gene expression studies to detect the ripening process during transportation. RNA is the genetic material that plays an important role in a series of gene expression process. RNA can be easy to degrade, especially if there any presence of RNase (Reece et al., 2011). Thus, damaging tissue samples can reduce the quality of RNA as well as the preservation method of the tissue sample, the length of delay in tissue sample preservation, RNA extraction procedures, and the presence of RNase

\footnotetext{
* To whom correspondence should be addressed.
}

(Salehi \& Najafi, 2014). In limited time or restricted procedures, such as the sample preparation for a space experiment, there are limited factors, such as refrigeration, transportation, and crew time required for the experiments (National Research Council, 2000).

Flash freezing is a standard method used to preserve banana flesh tissues using immersion in liquid nitrogen $\left(-195.79^{\circ} \mathrm{C}\right)$ and stored at $-80^{\circ} \mathrm{C}$ (Salehi \& Najafi, 2014). However, liquid nitrogen can be harmful to the body when used without caution. Preserving the sample in liquid nitrogen is more expensive compared to preservation in $-80^{\circ} \mathrm{C}$ freezers because liquid nitrogen evaporates rapidly (Andreasson et al., 2013). The direct storing sample method at $-80^{\circ} \mathrm{C}$ without using liquid nitrogen is an alternative preservation process for RNA extraction. Based on the results of Andreasson et al. (2013), temperatures of $-80^{\circ} \mathrm{C}$ can be used to store tissue samples for long periods without decreasing the quality of RNA. We aim to find the most excellent 
preservation method of RNA from banana flesh tissue to cope with the limited resources and prolong the experiment time when the ideal conditions cannot be executed.

\section{MATERIALS AND METHODS}

\section{Plant Materials}

We used the Cavendish banana (Musa acuminata AAA Group) from PT. Sewu Segar Nusantara after treating with ethylene. Bananas used in this study were ripe green banana (maturity stage 2 or Day-0) and yellow banana with freckles (maturity level at more than 7 or Day-8) with three biological replicates (Figure 1). Based on the maturity level of fruit, bananas were also selected based on the fruit size being relatively similar and with no injuries.

\section{Preservation Methods}

There were two significant treatments (Figure 2), the treatment method of preserving banana flesh tissue (flash freezing at temperature of $-80^{\circ} \mathrm{C}$ ) and the interval of banana cutting time $(0,19$, and 30 minutes). Interval of banana cutting time is the gap time from banana cutting process to the preservation treatment. At the interval of these cuts, the tissue samples were incubated at room temperature. Banana was cut at 0,19 , and 30 minutes, then treated with preservation methods. There are two methods of preservation of flesh tissue banana carried out in this research. Those who used flash freezing, and which directly stored at $-80^{\circ} \mathrm{C}$ without liquid nitrogen immersion.

\section{RNA Isolation}

Total RNA was isolated from banana fruit pulp using manual isolation method (Corderio et al., 2008) with some modifications. This isolation method lasted for two days. RNA quantity was determined using a Nanodrop and RNA quality was visualized on a $1 \%(\mathrm{w} / \mathrm{v})$ agarose gel with TAE buffer $1 \%$, the results of electrophoresis visualised under UV light.

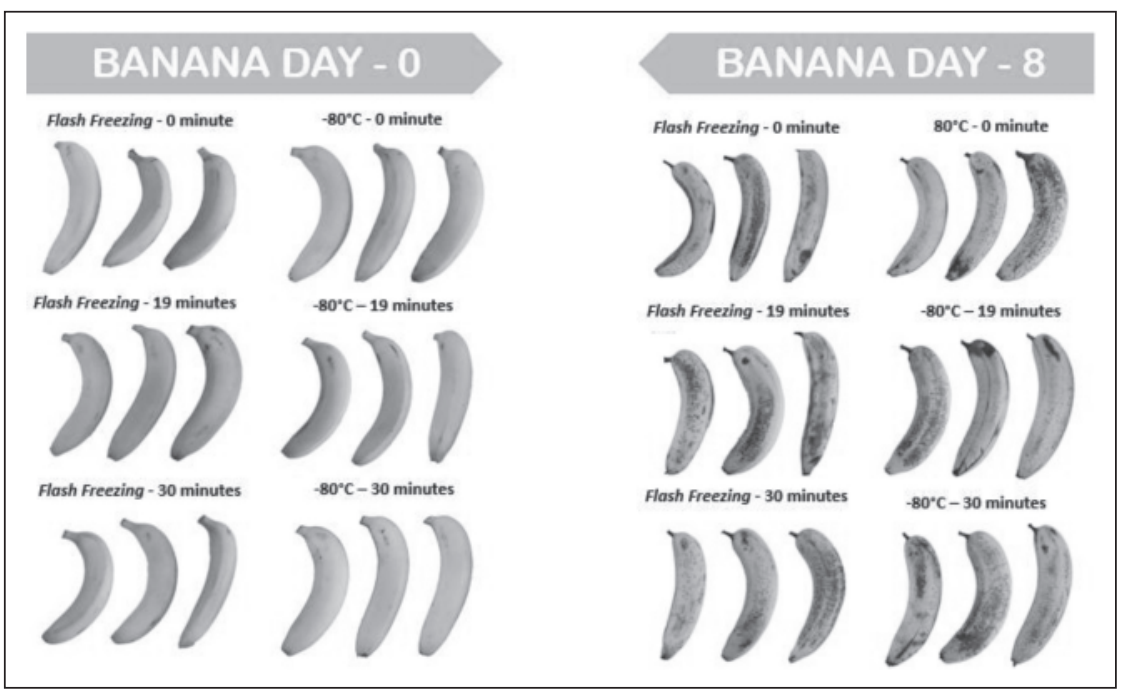

Fig. 1. Cavendish banana used in this research with various preservation methods.

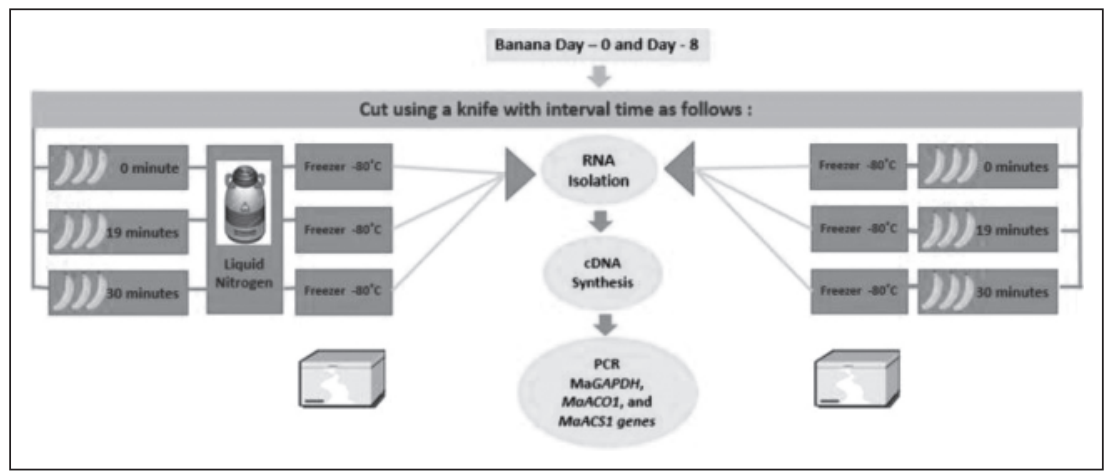

Fig. 2. Research scheme. 


\section{cDNA synthesis}

cDNA was synthesised using iScript ${ }^{\mathrm{TM}} \mathrm{cDNA}$ synthesis kit (Bio-Rad Laboratories, Inc.) according to the manufacture instructions. For each sample, one $\mu \mathrm{g}$ of total RNA was retro-transcribed and diluted 1:5. RT-qPCR reaction was performed in 10 $\mu \mathrm{L}$ total volume using $1 \mu \mathrm{L}$ of cDNA. The cDNAs are stored in the freezer at $-20^{\circ} \mathrm{C}$.

\section{Polymerase Chain Reaction (PCR)}

We used a housekeeping gene MaGAPDH AY821550.1 (Vieira et al., 2004) and banana ripening genes, MaACS1 (GQ406064.1) and MaACO1 (AJ223232.1) (Karmawan et al., 2008). PCR was performed using Gotaq ${ }^{\circledR}$ Green Master Mix kit from Promega (Catalog No. M7122) and Thermocycler machine. PCR profile was as follows: first denaturation at $94^{\circ} \mathrm{C}$ for 2 mins, first cycle (denaturation at $94^{\circ} \mathrm{C}$ for the $30 \mathrm{~s}$; extension $48.5^{\circ} \mathrm{C}$ for $30 \mathrm{~s}$ ) and run for 35 cycles. PCR results were confirmed by electrophoresis using agarose gel $1 \%$ $\mathrm{w} / \mathrm{v}$ with a $1 \%$ TAE buffer and visualised under UV light.

\section{RESULTS AND DISCUSSION}

\section{The purity of RNA}

The average value of the ratio of A260 /A280 of all sample treatment was 1.78-1.93 (Table 1), which means that all samples can be said to be 'pure'. As a result, no significant difference between the purity of RNA samples of flesh tissue bananas in preservation using flash freezing and preservation method which directly stored at $-80^{\circ} \mathrm{C}(P$-value $>$ $0.05)$ either at day-0 and day- 8 . There is no significant difference $(P$-value $>0.05)$ between the purity of RNA samples Cavendish banana flesh tissue with a cutting interval time of 0 minutes, 19 minutes, and 30 minutes before preserved, whether it was preserved using flash-freezing method nor in the directly stored at $-80^{\circ} \mathrm{C}$.

The average value of all sample concentration of RNA ranged between $410.256 \mathrm{ng} / \mu \mathrm{l}-736.923$ $\mathrm{ng} / \mu \mathrm{l}$. No significant difference between the RNA yield of flesh tissue bananas in preservation using flash-freezing method and preservation methods directly at $-80^{\circ} \mathrm{C}(P$-value $>0.05)$ either at day 0 and day 8 . Then, the statistical result also showed that there was no significant difference $(\mathrm{P}$ value $>0.05$ ) between the RNA yield of Cavendish banana fruit flesh tissue with a cutting interval time of 0 minutes, 19 minutes, and 30 minutes before preserved, whether it was preserved using flash-freezing method nor in the directly stored at $-80^{\circ} \mathrm{C}$.

\section{Visualisation of Total RNA}

Visualisation of total RNA isolated from whole sample treatment showed positive results that showed two thick bands (Figure 3). Both of these bands are rRNA sized $28 \mathrm{~S}$ and $18 \mathrm{~S}$, which is the essential rRNA cytoplasm in the plants (Heldt, 2005). Ribosomal RNA make up more than $80 \%$ of the total amount of RNA containing the majority expression of the $28 \mathrm{~S}$ and $18 \mathrm{~S}$ RNA. The number of large rRNA, both qualitatively and quantitatively, is assumed to be representative of the population of mRNA which amounted to only $1-3 \%$ of the total population. The little amount of mRNA is the reason that mRNA could not be detected, and to determine mRNA usually from the presence or absence of $28 \mathrm{~S}$ and 18S rRNA (Palmer, 2014).

\section{Expression of $M a G A P D H, M a A C S 1$, and $M a A C O 1$ Genes}

We found that MaGAPDH and MaACO1 genes (Figure 4) showed a similar size of less than $300 \mathrm{bp}$ and MaACS1 genes showed the size for less than

Table 1. The purity of RNA

\begin{tabular}{|c|c|c|c|c|}
\hline $\begin{array}{c}\text { Day of } \\
\text { Observation }\end{array}$ & $\begin{array}{l}\text { Preservation } \\
\text { Methods }\end{array}$ & $\begin{array}{l}\text { Cutting Time } \\
\text { (Minutes) }\end{array}$ & $\begin{array}{c}\text { The Purity Value } \\
\text { of RNA }\end{array}$ & $\begin{array}{l}\text { The RNA } \\
\text { Concentration }(\mathrm{ng} / \mu \mathrm{l})\end{array}$ \\
\hline & & 0 & $1.82 \pm 0.046$ & $464.104 \pm 92.692$ \\
\hline & Flash Freezing & 19 & $1.80 \pm 0.023$ & $410.256 \pm 89.080$ \\
\hline & & 30 & $1.84 \pm 0.030$ & $567.947 \pm 235.370$ \\
\hline \multicolumn{5}{|l|}{0} \\
\hline & & 0 & $1.84 \pm 0.046$ & $467.180 \pm 141.831$ \\
\hline & Freezer $-80^{\circ} \mathrm{C}$ & 19 & $1.78 \pm 0.038$ & $461.282 \pm 55.791$ \\
\hline & & 30 & $1.81 \pm 0.056$ & $614.103 \pm 112.152$ \\
\hline & & 0 & $1.84 \pm 0.053$ & $456.923 \pm 160.651$ \\
\hline & Flash Freezing & 19 & $1.89 \pm 0.029$ & $558.461 \pm 26.052$ \\
\hline & & 30 & $1.90 \pm 0.032$ & $658.204 \pm 103.070$ \\
\hline \multicolumn{5}{|l|}{8} \\
\hline & & 0 & $1.93 \pm 0.017$ & $736.923 \pm 121.568$ \\
\hline & Freezer $-80^{\circ} \mathrm{C}$ & 19 & $1.83 \pm 0.100$ & $415.385 \pm 176.300$ \\
\hline & & 30 & $1.85 \pm 0.058$ & $481.282 \pm 75.641$ \\
\hline
\end{tabular}




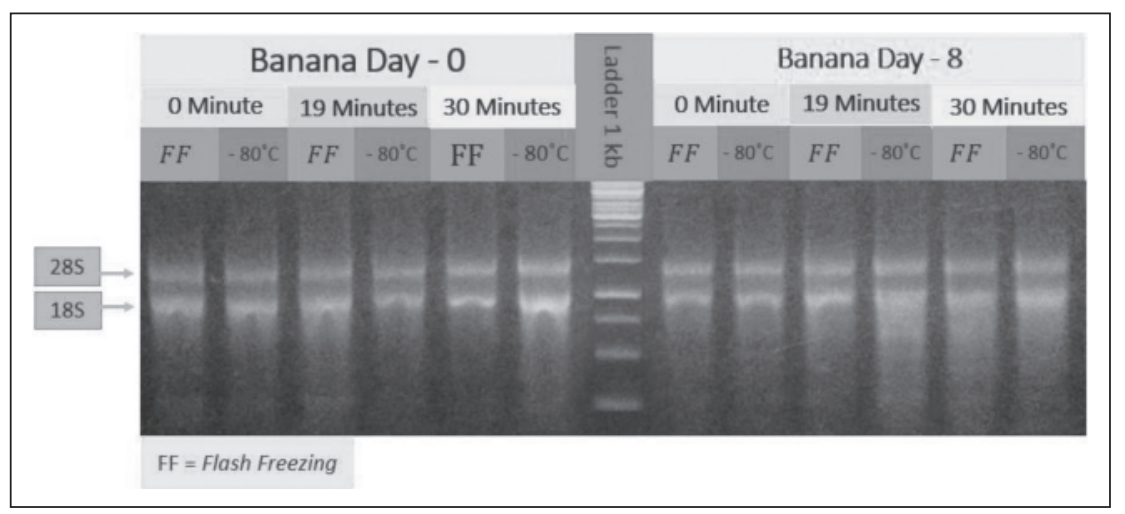

Fig. 3. Electropherogram of total RNA.

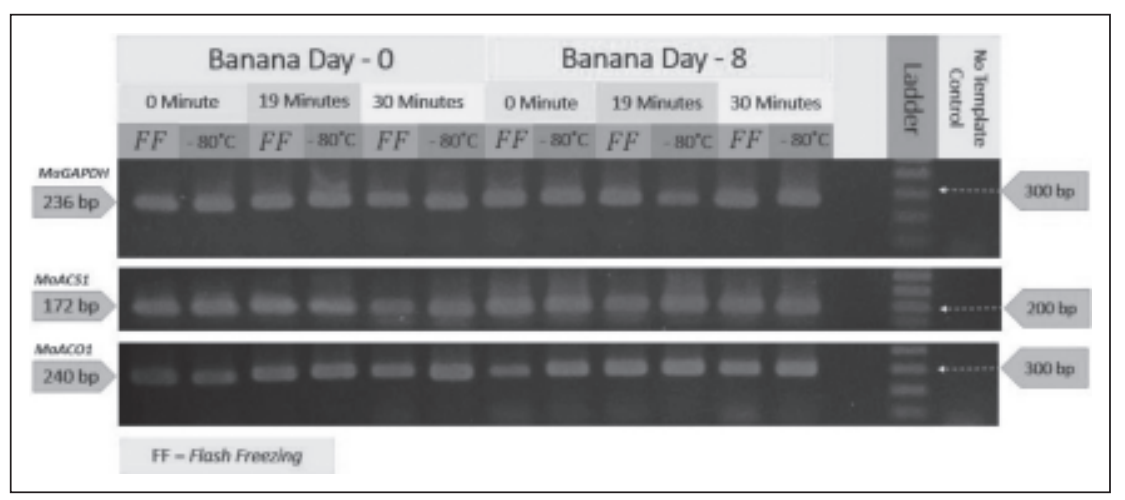

Fig. 4. Electropherogram of $M a G A P D H, M a A C S 1, M a A C O 1$ genes amplification.

200 bp. MaGAPDH gene size is 236 bp (Koolman, 2005). MaACS1 gene size is $172 \mathrm{bp}$, and MaACO1 gene size is 240 bp (Karmawan et al., 2008). Our findings were in agreement with the previous studies and indicated the expression of $M a G A P D H$, $M a A C S 1$, and MaACO1 genes.

In the case of preservation methods, a liquid nitrogen method $\left(-195.79^{\circ} \mathrm{C}\right)$ or ultra-low temperature $\left(-80^{\circ} \mathrm{C}\right)$ is common to be used to store tissue samples for RNA extraction purposes. Liquid nitrogen is a cryogenic liquid which can cause rapid freezing on contact with living tissue or certain substances. At extreme cold temperatures, the water content in the cells will be frozen (Pegg, 2007). Meanwhile, water is a solvent medium used to induce a variety of chemical reactions (Tarze et al., 2007). At shallow temperatures, all the chemical and enzymatic activity cease to work (Pegg, 2007; Handayani \& Dwivany, 2014). Based on the RNA purity, RNA yield, gene expression of $M a G A P D H$, $M a A C S 1$, and MaACO1, the direct preservation at $80^{\circ} \mathrm{C}$ (without liquid nitrogen) was successful without decreasing the quality of RNA. Also, the interval cutting time up to 30 minutes waiting time showed not affecting the quality of RNA related to the expression of banana ripening genes.

\section{CONCLUSION}

As a conclusion, no significant difference in the RNA quality of banana flesh tissues and expression analysis of banana ripening genes marker (MaGAPDH, MaACS1, and MaACO1) using liquid nitrogen, direct store at $-80^{\circ} \mathrm{C}$ refrigerator or the various cutting interval time. Our preservation methods can be used in the future if the ideal conditions in the field or the laboratory cannot be reached.

\section{ACKNOWLEDGEMENTS}

The authors thank Dr Fenny M. Dwivany for her fruitful comments, discussion, and support from Banana Research Group, Institut Teknologi Bandung. The authors would like to acknowledge the funds obtained from the Biosciences and Biotechnology Research Center, Institut Teknologi Bandung in "Riset Unggulan" Scheme 2016, and School of Life Sciences and Technology, Institut Teknologi Bandung for allowing the use of laboratory facilities during this research. 


\section{REFERENCES}

Andreasson, A., Kiss, N.B., Juhlin, C.C. \& Ho, A. 2013. Long-Term Storage of Endocrine Tissues at $-80^{\circ} \mathrm{C}$ Does Not Adversely Affect RNA Quality or Overall Histomorphology. 11(6): 366-370.

Corderio, M.C.R., Silva, M.S. \& Oliveira-Filho, E.C. de. 2008. Optimization of A Method of Total RNA Extraction From Brazilian Native Plants Rich In Polyphenols and Polysaccharides. Simp Int savanas Trop, 1-6.

Handayani, R.U. \& Dwivany, F.M. 2014. Analysis of MaACS2, a stress-inducible ACC Synthase Gene in Musa acuminata AAA Group Cultivar Pisang Ambon. J Math Fund Sci., 46(2): 194203.

Heldt, H. 2005. Plant Biochemistry Third Edition. USA: Elsevier Academic Press.

Karmawan, L.U., Suhandono, S. \& Dwivany, F.M. 2008. Identifikasi Famili Gen MaACS dan Studi Ekspresi Gen Ma-ACS1 pada Buah Pisang Musa acuminata (AAA GROUP) Kultivar Pisang Ambon Lumut Menggunakan Real-Time PCR. J Hayati Biosci., 16(1): 35-39.

Koolman, J.K.R. 2005. Color Atlas of Biochemistry Second Edition. New York: Thieme.

Molina, A.B., Roa, V.N. \& Van den Bergh, I.M. 2005. Advancing banana and plantain R \& amp; $\mathrm{D}$ in Asia and the Pacific Vol. 12 - Molina, A.B., Roa, V.N., Van den Bergh, I., Maghuyop, M.A. Bioversity Int. 13.
National Research Council. 2000. Future Biotechnology Research on the International Space Station. Washington, DC: The National Academies Press.

Palmer, M. \& P.E. 2014. Assessing RNA Quality.

Pegg, D.E. 2007. Principles of Cryopreservation. Methods Mol Biol., 368: 39-57.

Reece, J.B., Urry, L.A., Cain, M.L., Wasserman, S.A., Minorsky, P.V. \& Jackson, R.B. 2011. Campbell Biology Ninth Edition. USA: Pearson.

Salehi, Z. \& Najafi, M. 2014. Biochemistry \& Physiology/: Open Access RNA Preservation and Stabilization. Biochem Physiol., 3: 126.

Tarze, A., Deniaud, A., Bras, M. Le., Maillier, E., Molle, D., Larochette, N., Zamzami, N., Jan, G., Kroemer, G. \& Brenner, C. 2007. GAPDH, a novel regulator of the pro-apoptotic mitochondrial membrane permeabilization. Oncogene, 26(18): 2606-2620. doi:10.1038/ sj.onc. 1210074.

Vieira, A. Jr., Nascimento, J.R.O. \& Lajolo, F. 2004. Molecular cloning of a cDNA encoding GAPDH homolog from banana (Musa ssp.). Direct Submiss NCBI. 
